Journal of Marketing Management, Vol.24, Nos.7-8, September 2008, Pp.847-864

\title{
Determining the indirect value of a customer
}

Professor Lynette Ryals, MA (Oxon), MBA, PhD, FSIP

Professor of Strategic Sales and Account Management

Centre for Advanced Research in Marketing

Cranfield School of Management

Cranfield University

Cranfield

Bedford MK43 OAL*

Tel: 01234751122

Fax: 01234752158

email: lynette.ryals@cranfield.ac.uk

${ }^{*}$ Address for correspondence

Submitted to: Journal of Marketing Management

Special issue: Marketing / Finance interface

First submission: $\quad 20^{\text {th }}$ December 2006

Date of resubmission: $\quad 11^{\text {th }}$ February 2008

Accepted:

$4^{\text {th }}$ June 2008

Word count: $\quad 4,884$ excluding figures, tables and references 


\section{Determining the indirect value of a customer}

The issue of accountability in marketing has led to a substantial and growing body of work on how to value customer relationships. Net present value methods (customer lifetime value / customer equity) have emerged as generally preferred ways to assess the financial value of customers. However, such calculations fail to take account of other important but indirect sources of value noted by previous researchers, such as advocacy. This paper examines the development and application of three processes to determine indirect value in business-to-business and business-to-consumer contexts. The research shows that indirect value has a measurable monetary impact not captured by conventional financial tools, and that understanding this changes the way in which customers are managed.

Keywords: customer lifetime value, customer equity, indirect value, advocacy

\section{Author's Biography:}

Lynette Ryals MA (Oxon) MBA PhD FSIP

Professor of Strategic Sales and Account Management, Cranfield School of Management

Lynette specializes in key account management and marketing portfolio management, particularly in service businesses, and has completed a $\mathrm{PhD}$ on customer profitability. She came into marketing from a financial background and much of her work focuses on the marketing / accounting interface. She is a Registered Representative of the London Stock Exchange and a Fellow of the Society of Investment Professionals. Lynette is the Director of Cranfield's Key Account Management Best Practice Research Club and of the Demand Chain Management community, which includes faculty in Marketing, Sales and Supply Chain Management. As well as the Journal of Marketing Management, her work has been published in the Journal of Marketing, European Journal of Marketing, and Industrial Marketing Management. 


\section{INTRODUCTION}

The advent of relationship marketing has had a profound impact on the marketing / finance interface. Relationship marketing focuses on customers and long-term relationship building rather than on products (Christopher, Payne and Ballantyne 2003). A major implication of relationship marketing is that marketing decisions should be about optimising the long-term value of the customer (Berger and Bechwati 2001). Consequently, accounting for marketing has shifted from the traditional product profitability approach (Grant and Schlesinger 1995) to a customer profitability focus.

The new focus has revealed that customer profitability is principally determined not by the cost of the products that the customer buys, but by the costs of managing the customer relationship (Kalwani and Narayandas 1995; Reinartz and Kumar 2002). This is particularly an issue in business-tobusiness markets, in which substantial proportions of sales and marketing resources may be allocated to individual customers (Bowman and Narayandas 2004). Overspending on customer retention can mean that retained customers are not necessarily more profitable (Thomas, Reinartz and Kumar 2004), and the influence of customer management activities on the profitability of customers is well-attested (Bowman and Narayandas 2004; Ryals and Knox 2004; Ryals 2005).

Focusing on the profitable management of customer relationships has also helped to address the calls for greater accountability in marketing (Doyle 
2000 ), since the value of customers is related to the value of the firm (Gupta, Lehmann and Stuart 2004). Previous research has found two sources of value from customers: financial (measured by the profitability or lifetime value of the customer) and indirect (other value from the relationship that is not directly related to the financial value of that customer). A review of the literature on the financial value of the customer reveals that mainstream methods for valuing customers do not take indirect value sufficiently into account, despite its acknowledged importance. The paper goes on to examine how two companies have addressed this issue and determined the indirect value of their customers, and how this information changed their customer management strategies.

\section{CALCULATING THE DIRECT FINANCIAL VALUE OF A CUSTOMER}

The growing requirement to monitor how investments in customer management pay off over time has meant that customer lifetime value and customer equity approaches to valuing customers have become widely accepted (Jain and Singh 2002; Gupta and Lehmann 2003; Ambler and Roberts 2005). Customer lifetime value is the value of a customer relationship over the course of the relationship lifetime (e.g. Reichheld and Sasser 1990; Reichheld 1996; Reichheld and Schefter 2000). Customer equity is the total lifetime value of a company's customer base (e.g. Blattberg, Getz and Thomas 2001; Lemon, Rust and Zeithaml 2001; Rust, Lemon and Zeithaml 2001). 
Table 1 sets out a definition of each financial approach, its advantages and disadvantages, and its application to marketing practice.

\section{- Bring in Table 1 near here -}

To calculate customer lifetime value, marketers must forecast the likely length of the relationship lifetime and then the customer profitability or cash flow each year (Ryals and Knox 2004). Customer acquisition costs for an existing customer are generally disregarded (Berger and Nasr 1998), although they may be included for a new or returning customer (Calciu and Salerno 2002). These future profits are then discounted back to present day monetary amounts (Jain and Singh 2002). Thus, in accounting terms, calculating customer lifetime value is about forecasting the net present value of a customer.

Where the lifetime value relates to a number of customers and takes potential value into account, it is known as customer equity (Blattberg, Getz and Thomas 2001). 'Potential value' involves forecasting likely additional future purchases, increase in share of spend etc. Because of the larger sample numbers, customer equity is amenable to the use of forecasting tools such as acquisition / retention modelling (Berger and Bechwati 2001), decision calculus, regression analysis, neural networks (Berger and Bechwati 2001), Delphi panels (Story, Hurdley, Smith and Saker 2001), or Markov techniques (Rust, Lemon and Zeithaml 2001). 
Applying customer lifetime value / customer equity to marketing decisionmaking

Marketing managers are increasingly interested in understanding customer lifetime value as a guide to the way they manage customer relationships (EIU 1998). Lifetime value is affected by the way in which the relationship is managed but may also be affected by exogenous factors such as the actions of competing suppliers or changes in the customer's own circumstances. Generally, however, customers with high lifetime value will be preferred targets for retention strategies; customers with low or negative lifetime values might be better managed through cheaper channels or via a third party such as a distributor, or offered a lower service package (Booz Allen and Hamilton 2002).

Since the way in which the customer is managed has a major impact on lifetime value (Kalwani and Narayandas 1995; Reinartz and Kumar 2002), calculating customer lifetime value should not be seen as a one-off exercise but as dynamic (Jain and Singh 2002). Resource allocation decisions should aim to optimise returns on the marketing investment.

Customer equity is a portfolio-based measure and is associated with the notion of customers as assets (Blattberg and Deighton 1996; Blattberg, Getz and Thomas 2001; Hogan, Lemon and Rust 2002). The marketing applications of customer equity relate to budget setting and allocation (Berger and Bechwati 2001), balancing customer acquisition and retention activities 
(Thomas, Reinartz and Kumar 2004) and profitable customer management (Zeithaml, Rust and Lemon, 2001).

Weaknesses of customer lifetime value / customer equity tools

Recent research has revealed three weaknesses that affect both tools forecasting, discounting, and whether the tools really do measure all the value generated by customers.

The first two difficulties have been explored elsewhere. It is known that forecasting difficulties have limited the take-up of customer lifetime value by practitioners (Gupta and Lehmann 2003). On the discounting issue, some marketers have become concerned that the use of a single discount rate may not reflect the risk in certain customer relationships and have developed additional techniques, either adjusting the discount rate or assessing the relationship risk and thus the probability of future profits (Dhar and Glazer 2003; Ryals and Knox 2004; Malthouse and Blattberg 2005).

The third issue is that these tools do not fully reflect the value of customers to the firm (Hogan, Lemon and Rust 2002; Ambler and Roberts 2005; Haenlein, Kaplan and Schoder 2006). For example, customer equity calculations do not usually include the value of potential customers (those yet to be acquired), yet advocacy from existing customers may help attract them. Even where the value of potential customers is included in the customer equity calculation (Rust, Lemon and Zeithaml 2004), the customers acting as advocates are 
undervalued. Advocacy, and other indirect sources of value from customers not captured by conventional tools, will now be discussed.

\section{THE INDIRECT VALUE OF A CUSTOMER}

The indirect value of a customer is the additional value (over and above the direct financial value measured by customer lifetime value / customer equity) that accrues to the firm through their relationship with that customer. Perhaps the most-explored area is advocacy, or word of mouth, early identified as an important element of relationship marketing (Christopher, Payne and Ballantyne 1991) and associated not just with satisfaction but also with relationship duration (e.g. Reichheld 1996). Advocacy has repeatedly been shown to have a strong impact on purchasing behaviour (Murray 1991; East et al. 2005; Keaveney 1995) and can be influenced by marketing strategies (East et al. 2005). Consequently, it is positively correlated with company growth (Reichheld 2003; East et al. 2005; Marsden, Samson and Upton 2005).

The advocacy concept has been extended to include customer reputation or referenceability (Doney and Cannon 1997; Stahl, Matzler and Hinterhuber 2003). Burnett (1992:12) describes this as "the kudos of being a supplier to Harrods". Advocacy and referenceability positively impact firm performance by reducing customer acquisition costs and by increasing sales through the attraction of new customers (Stahl, Matzler and Hinterhuber 2003). 
Further relational benefits from customer relationships include learning (Womack et al. 1990; Wilson 1996; Hope and Hope 1997; Srivastava, Shervani and Fahey 1998; Stahl, Matzler and Hinterhuber 2003) and innovation (Wilson 1996; Thomke and von Hippel 2002). Learning and information benefits contribute slightly differently to the value of the firm. Rather than reducing the costs of customer acquisition, they enhance the overall competitiveness and revenues / efficiency of the firm (Cravens, Piercy and Prentice 2000; Stahl, Matzler and Hinterhuber 2003).

It is difficult to account for indirect value. For example, the impact of advocacy or reference benefits is to reduce the cost of customer acquisition, which increases the financial value of the acquired customer but does not affect the value of the referring customer. Learning and innovation benefits may or may not increase the financial value of the customer generating them, through increased sales or reduced costs, but they can also increase the overall revenues or improve the overall efficiency of the supplier (Table 2).

\section{- Bring in Table 2 -}

Table 2 illustrates the difficulty of evaluating indirect value in financial terms. Jenkinson (1995) suggests adding the revenues generated from relational benefits to the calculation of the value of the customer, although it is unclear how this is to be done without double counting (Ryals 2002). Since the indirect value of a customer relationship is usually described as additive to the financial value (e.g. Wilson 1996; Stahl, Matzler and Hinterhuber 2003), 
current financial valuation models based solely on net present value using customer lifetime value or customer equity probably understate the value created by customers. To find out how serious this understatement is, companies need to determine the indirect value of their customers. Figure 1 illustrates these two sources of value from customer relationships, financial and indirect.

\section{- Bring in Figure 1 near here -}

The purpose of the current research was to explore how marketing and account managers could place a value on indirect benefits and whether the results would change the way in which those customer relationships were managed.

\section{METHODOLOGY}

The research approach was exploratory and descriptive, so a case study method was chosen (Patton and Appelbaum 2003). Two participating companies were selected to explore the process of valuing indirect benefits (Eisenhardt 1989; Yin 2002). Both participating companies were large international corporations from the financial services industry, one businessto-business and the other business-to-consumer. The companies met the theoretical sample requirements (Patton and Appelbaum 2003) which, in this case, were acceptance of the need for measurement of indirect value; an established customer management operation; good data-gathering processes; and a relative familiarity with the financial valuation of customers 
using customer lifetime value or customer equity approaches. Case study 1 , a business-to-business case study, examined indirect value for major customers whose individual lifetime value had already been forecast. Case study 2, a business-to-consumer example, examined a set of customers whose customer equity had already been forecast.

The methodology was inductive, using one-on-one interviews and team-based workshops (Gummesson 2000) to collect both quantitative and qualitative data (Yin 2002). These data were used to develop pro-formas or produce provisional results that were then discussed at further interviews and workshops. Multiple iterations were carried out and, at each stage, the participating marketing and account managers were asked about the results and the implications for customer management practices.

The research produced interesting results relating both to processes for measuring the indirect value of customer assets and to the impact on customer management of applying these processes.

\section{RESULTS: CASE STUDY 1}

Case study 1 (business-to-business) focused on a small number of individual customers all having high customer lifetime value and where the indirect value was thought to be important. Eight customers who accounted for $47 \%$ of the customer portfolio by revenue were selected for study. Two processes for calculating indirect value were explored, one subjective and the other 
monetary. The first process used a weighting and scoring system (WSS); the second process imputed additional financial value directly to the relationship with individual customers.

The WSS process began with a workshop to explore whether, unprompted, the managers would identify the same relational attractiveness factors that had been identified in the literature. In fact, only one factor overlapped. This was Profile, identifiable as referenceability (Table 3).

\section{- Bring in Table 3 here -}

These results suggest that indirect value is not well understood, even for more important customers. Three of the four 'indirect value' factors identified by the account managers during the first iteration (Relationship, Resources, and Skill Demands) turned out to affect costs to serve and ought therefore to be considered under the heading of direct financial value.

Figure 2 shows the results of the second iteration. Financial attractiveness

was based on customer lifetime value, and the size of the circle indicated whether the customer was relatively high, medium or low revenue).

\section{- Bring in Figure 2 here -}

Figure 2 is suggestive of a relationship between financial and indirect attractiveness. There are some practical reasons that this might be true: 
larger customers are likely to be bigger, better-known companies with higher referencability and greater learning and innovation value. However, the initial outputs of the WSS process (Table 3) also indicated a tendency for managers to confuse financial and indirect value. More research would be needed to establish the relationship between financial and indirect value, using an objective valuation method such as those discussed below.

Although the WSS process for determining indirect value suffered from some drawbacks as described above, it did help the managers in this team to resolve a current business issue relating to how they could identify their company's key accounts (Figure 3). Figure 3 uses the convention for customer portfolios of a reversed $X$ axis (e.g. McDonald, Rogers and Woodburn 2000).

\section{- Bring in Figure 3 here -}

Figure 3 illustrates an additional finding from this case study, which was that the identification of a key account might take account of both financial and indirect value. Although high financial value was a strong identifier of key account status, high indirect value might also be sufficient for key account status. This was the case for customers such as C and F shown in Figure 2, whose indirect value was considerably higher than their financial value. The WSS process also resulted in managerial action in the case of low-scoring customer $\mathrm{H}$, shown towards the bottom of Figure 2. Examining the results, the managers felt that H's relatively low financial and indirect value meant that it 
should no longer be considered a key account. They made a decision to reduce its status; service levels and customer management practices were adjusted accordingly. The analysis summarised in Figure 2 enabled the team to make clearer decisions about which customers should - and should not be considered as key accounts.

The second process tested in case study 1 was whether specific financial amounts could be attributed to indirect value.

\section{Putting a financial value on indirect value}

Following consultations with the research company finance managers and with finance academics, a probabilistic forecasting process was selected to put an expected monetary value on relational benefits. The probabilistic process reduced the problem of double counting noted by Jenkinson (1995) and Ryals (2002) whilst still resulting in a noticeable difference to the value of the customer.

For trialling purposes, major customer $\mathrm{G}$ was considered. The managers felt that the most likely type of relational benefit from $G$, which is a large and highprofile drinks company, was customer attraction through referenceability and advocacy. The managers forecast that their relationship with customer $\mathrm{G}$ was certain to help them win one new customer the following year and likely to help them win two new customers in year 2 and a fourth customer in year 3. Without customer G, there would be a zero probability of acquiring these customers. Moreover, probabilities of benefits in future years would be 
contingent on the relationship in earlier years, so conditional probabilities were used to calculate the monetary impact. Assuming a discount rate of $10 \%$, the net present financial value of the increased probability of customer acquisition thanks to the relationship with customer $G$ was $£ 468,538$ (Table 4).

\section{- Bring in Table 4 -}

In all, this exercise was repeated for four of the eight customers and resulted in an increase of $6.4 \%$ in the total net present value of those four customers. There were considerable differences in the perceived indirect benefits, with fully $76 \%$ of relational benefits identified as relating to customer $\mathrm{G}$. Determining the expected monetary amount of G's indirect value resulted in an increased focus on continuing this relationship; as one key account manager commented:

"If we build up positive relationships with customers and learn from them, those customers also wish to learn from us and then we continue to work together and grow..."

The probabilistic forecasting method necessitates a series of assumptions about the acquisition timing and financial value of potential customers. The case demonstrates empirically that managers were able to apply the process and generate financial numbers that seemed realistic to them as a proportion of the value of customer $\mathrm{G}$. The findings also suggested that indirect value 
might differ considerably between customers. This differential would be an interesting topic for future research.

\section{RESULTS: CASE STUDY 2}

The second case study, also in financial services, was in a very different context. Here, business-to-consumer research was carried out within the retail loans department of a bank. This case study was based on an examination of 123,442 loan applications by customers representing $100 \%$ of applications during a three-month period.

An initial workshop with the marketing managers quickly established that the WSS process was not viable with this sample size. Moreover, there were limited indirect benefits because the lender did not identify its customers publicly or exploit its relationships. At the time of the case study the bank was not collecting formal data about advocacy because it was not believed to be financially valuable, even though the bank's own research data suggested reasonably high intention to advocate. As one of the senior marketing managers observed at the beginning of the process:

"If I'm honest, I'm a bit sceptical about whether there will actually be sufficient numbers to make it worthwhile but, unless you investigate it ... you'll never know." 
The data in Table 5 were drawn from a re-analysis of marketing research data over the three-month period and based on the responses of 300 customers per month (900 responses in total).

\section{- Bring in Table 5 -}

Table 5 shows that customer satisfaction within the loans department was higher than for the company as a whole, although complaints were also substantially higher. This dichotomy illustrates a known problem with customer satisfaction as a predictor of repurchase (Reichheld 2003). A subsequent regression analysis carried out by the bank determined that advocacy was a more useful predictive measure than customer satisfaction, supporting Reichheld's (2003) contention. As one of the marketing analysis commented:

"A very large chunk of the people who say they are completely satisfied, it is simply because we haven't done anything wrong. It's not because they are delighted with us."

\section{Putting a monetary value on advocacy}

As the bank had no data on the actual incidence of referrals, the research focused on estimating the monetary value of advocacy based on triangulating an output measure (proportion of advocates) drawn from live data, with input measures (proportion of customers where advocacy was a declared reason influencing purchase) generated from two sources: research estimates and manager interviews. First, the marketing and database managers made 
estimates of the value of advocacy based on analysis of customer records and behaviour. These estimates were then triangulated through primary research with managers who were selling loans.

Having identified those customers most likely to refer, the marketing and database managers estimated the proportion of those saying that they were 'very likely' to refer who would actually do so (one third). This yielded a figure of 8,500 customers per month who were predicted to be advocates and a further estimate that one in 10 recommendations resulted in an application. Given that the company rejected $46 \%$ of loan applications, this would represent 457 converted customers per month. Multiplied by the average value of a customer, this would yield an estimate of the financial value of advocacy of $£ 188,100$ in revenue per quarter $(0.75 \%$ of total revenue) and $£ 81,140$ in profits per quarter (just over $0.7 \%$ ).

These estimates of the financial value of advocacy made by the marketing managers were triangulated against interviews with six loan managers and branch managers in four typical branches. These interviewees, who all spend the majority of their time selling loans to customers, estimated that advocacy accounted for $2 \%$ to $3 \%$ of incoming customers which translated into 440 to 660 customers per month. This estimate was noticeably higher than the projections of the marketing managers, suggested that the impact of advocacy had been understated by the central marketing team. Moreover, the loans managers were only reporting on the customers who had volunteered information about advocacy during the application process. As there was no 
formal requirement to ask loan applicants why they had applied, it is likely that many more incidents of advocacy went unreported.

However, in financial services it is not just revenues but risk that is important, and the branch office interviews produced some intriguing observations about the types and risk profiles of the customers arriving as a result of recommendation (Table 6).

\section{- Bring in Table 6 -}

As Table 6 shows, the managers identified three categories of referral: Family (thought to be most prevalent); Peer; and Colleague. Moreover, an interesting observation was that the risk profile of the customer was felt by the managers to be similar to, or the same as, that of the advocate.

The managers noted several implications of this research for their marketing strategy. The first was that advocacy was sufficiently prevalent to make it worthwhile tracking which customers had come through referral by including a specific question to that effect on the loan application form. The second was that the risk profile of the family, not just of the applicant, might be taken into account when making a loan to the close relative of an existing customer. Third, the firm could analyse its database to identify clusters of customers all working for the same company; this would be indicative of advocacy by a business colleague. Finally, if the firm wanted to encourage referrals, it would have to ensure that its pricing strategy was consistent with its advocacy 
strategy. The branch managers commented that sometimes they only became aware that a customer was there as a result of advocacy when the customer queried the rate (price) for the loan and complained that their relatives, friends or colleagues had got better deals:

"If they're not getting the same rate as their friends or whoever they've been talking to is getting, that can be a little bit difficult."

The research resulted in a change in advice to branch managers about how customer relationships were to be managed:

"While we still look at satisfaction, in terms of driving the things that we want staff to do with customers there is much more that is actually under their control in terms of relationship building with recommendation [referrals] than there is with satisfaction."

\section{DISCUSSION}

In recent years there has been considerable exploration of the financial value of customers. The need for net present value approaches (customer lifetime value and customer equity) is now widely accepted. However, research has also indicated that customers can create additional indirect value (e.g. Stahl, Matzler and Hinterhuber 2003). This research used a case study approach to identify and test three processes for evaluating the indirect value of a 
customer. The three methods, and their advantages and disadvantages, are summarised in Table 7.

\section{- Bring in Table 7 -}

In case study 1, two processes were used. The indirect value of customers was measured first with a WSS and then using a probabilistic forecasting approach. The WSS approach resulted in a managerial tool for the identification of key accounts and a decision to downgrade one company to non-key account status, changing the way that it was managed. The second, probabilistic approach indicated that relational benefits could be substantial and might be positively associated with financial value, although more research would be needed to determine the accuracy of probability estimates. Managerially, the findings confirmed the importance of one particular customer that was already known to be financially attractive. The discovery of substantial indirect benefits increased the customer management team's investment in this account.

In case study 2 , the indirect value of customers was thought to consist entirely of advocacy. In the event, three sources of advocacy were identified: Family, Peer, and Colleague. Of these, Family advocacy was thought to be the most frequent although Peer or Colleague advocacy could result in the acquisition of multiple customers and so might be more valuable overall. Managers also noted that the source of referral might indicate the risk of the acquired customer. These findings led to a reassessment of the importance of 
advocacy to the company that also affected pricing and loan acceptance decisions.

The wider applicability of this research is to supplement and extend the concept of customer lifetime value / customer equity. Typically, such calculations incorporate the stream of future value from one customer or group of customers, usually measured in terms of future product or service purchases. It is rare for such calculations to include consideration of the value of advocacy, referencability, learning, or innovation. This research demonstrates three methods for calculating indirect value and attributing it to the customers who are generating that value. The empirical testing of these methods reveals that indirect value can be substantial, and may result in changes to customer management.

\section{Limitations and future research}

The limitations of this research relate to the generalisability of the results from two case studies, both in financial services and both examining contractual relationships. In the first case study, only eight customers were studied and detailed financial evaluation of indirect value was completed on just four. However, these were major customers and the monetary value attributed to the relational aspects of the relationship was considerable. In the second case study, the sensitive nature of the product (personal loans) and the firm's existing customer management practices meant that indirect value was confined to advocacy. It is uncertain whether other sources of indirect value could be obtained from these relationships if they were managed differently. 
Several questions for future research are set out in Table 8.

\section{- Bring in Table 8 -}

The first question for future research is whether financial and indirect value are positively related. If customers with a higher lifetime value also have a higher indirect value, this would provide further substantiation for customer management practices such as key account management and CRM. A second question relates to the subjectivity of probability evaluations by account managers; it is not clear whether the change in probability of a relational benefit can accurately be measured.

Additional future research questions are raised by case study 2 , which raised the intriguing possibility that the risk/ return profiles of referred and referring customers might be similar. If this is generally the case, companies need to think carefully about which customers they target for referrals (Reichheld 2003), particularly in sectors such as financial services. This case study also suggests that the main indirect value in business-to-consumer services might be advocacy. There are some indications of this in East et al. (2005), although they find a much higher impact of advocacy in other service industries than was the case in the current research.

\section{CONCLUSION}


The contribution of the paper was to propose and empirically test three processes for evaluating the indirect value of a customer, demonstrating that these processes produced managerially useful results that 'fill a gap' in conventional tools that measure the financial value of customers. The first process (WSS) needed care in application to prevent overlap between financial and indirect value, but produced a tool that helped the managers identify key accounts. The other two processes enabled the companies to impute a monetary amount to indirect value. This information was then used to shape customer acquisition and management strategies.

Overall, this research has demonstrated that managers can put a value on advocacy. It has also demonstrated that determining the indirect value of a customer is not only feasible but is managerially useful, as it leads to changes in the way that the customer is managed. Indirect value may influence the identification of key accounts. It may also, through like-for-like advocacy, affect the risk profile of the customer base as well as its returns.

The research provides an extension to the widely-used tools of customer lifetime value and customer equity, demonstrating that there are substantial indirect benefits from customers that are not usually captured in conventional financial calculations. 


\section{REFERENCES}

Ambler, T. and Roberts, J. (2005), "Beware the Silver Metric: Marketing Performance Measurement has to be Multidimensional", Centre For Marketing Working Paper, 05-207 (September), London Business School.

Berger, P.D. and Bechwati, N.N. (2001), "The allocation of promotion budget to maximise customer equity", Omega, Vol. 29, No. 1, pp.49-61

Berger, P.D. and Nasr, N.I. (1998), "Customer lifetime value: Marketing models and applications", Journal of Interactive Marketing, Vol. 12, No. 1, pp.17-30

Blattberg, R.C. and Deighton, J. (1996), "Manage marketing by the customer equity test", Harvard Business Review, Vol. 74, No. 4, pp.136-144.

Blattberg, R.C., Getz, G. and Thomas, J.S. (2001), Customer Equity: Building and Managing Relationships as Valuable Assets, Boston, Harvard Business School Press

Booz Allen Hamilton Inc (2002), "The Customer Profitability Conundrum: When to Love 'Em or Leave 'Em”, Strategy + Business / Knowledge@Wharton, 10 April 2002

Bowman, D. and Narayandas, D. (2004), "Linking Customer Management Effort to Customer Profitability in Business Markets", Journal of Marketing Research, Vol. 41, No. 4, pp.433-447

Burnett, K. (1992) Strategic Customer Alliances: How to win, manage, and develop key account business in the 1990s, London, Pitman.

Calciu, M. and Salerno, F. (2002), "Customer Value Modelling: Synthesis and extension proposals", Journal of Targeting, Measurement and Analysis for Marketing, Vol. 11, No. 2, pp.124-147

Christopher, M; Payne, A and Ballantyne D. (1991), Relationship Marketing, Oxford, Butterworth Heinemann

Christopher, M; Payne, A and Ballantyne D. (2003), Relationship Marketing. $2^{\text {nd }}$ edition, Oxford, Butterworth Heinemann

Cravens, D.W., Piercy, N.F. and Prentice, A. (2000), "Developing market-driven product strategies" Journal of Product and Brand Management, Vol. 9, No. 6, pp.369-388

Dhar, R and Glazer, R. (2003), "Hedging Customers", Harvard Business Review, Vol. 81, No. 5, pp.86-92

Doney, P.M. and Cannon, J.P. (1997), "An Examination of the Nature of Trust in Buyer-Seller relationships" Journal of Marketing, Vol. 61, No. 2, pp.35-51

Doyle, P. (2000), "Valuing Marketing's Contribution”, European Management Journal, Vol. 18, no. 3, pp.233 - 245

East, R. Hammond, K. Lomax, W. and Robinson, H (2005), "What is the Effect of a Recommendation?", Marketing Review, Vol. 5, No. 2, pp.145-157

Eisenhardt, K.M., (1989), "Building Theories from Case Study Research", Academy of Management Review, Vol. 14, No. 4, pp.532-550

EIU (1998), "Managing customer relationships", The Economist Intelligence Unit, Report with Andersen Consulting. London, EIU

Grant, A.W.H. and Schlesinger, L.A. (1995), "Realise your Customers' full profit potential”, Harvard Business Review, Vol. 75, No. 5, pp.59-72

Gummesson, E. (2000), Qualitative Methods in Management Research, Sage, London, $2^{\text {nd }}$ Edition, Chap. 4, pp.83-156

Gupta, S. and Lehmann, D. R. (2003), "Customers as Assets", Journal of Interactive Marketing, Vol. 17, No. 1, pp.9-24 
Gupta, S., Lehmann, D.R and Stuart, J.A. (2004), "Valuing Customers", Journal of Marketing Research, Vol. 41, No. 1, pp.7-18.

Haenlein, M; Kaplan, A. M. and Schoder, D. (2006), "Valuing the Real Option of Abandoning Unprofitable Customers When Calculating Customer Lifetime Value" Journal of Marketing, Vol. 70, No. 3, pp. 5-20

Hogan, J. E. Lemon, K. N. and Rust, R. T. (2002), "Customer Equity Management: Charting New Directions for the Future of Marketing", Journal of Service Research, Vol. 5, No. 1, pp.4-12

Hope, J and Hope, T. (1997). Competing in the Third Wave, Boston, Harvard Business School Press

Jain, D. and Singh, S. S. (2002), "Customer lifetime value research in marketing: a review and future directions", Journal of Interactive Marketing, Vol. 16, No. 2, pp.34-46

Jenkinson, A. (1995). Valuing your Customers: From quality information to quality relationships. McGraw Hill, London

Kalwani, M.U. and Narayandas, N. (1995), "Long-term manufacturer-supplier relationships: do they pay off for supplier firms?", Journal of Marketing, Vol. 59, No. 1, 1-16. January

Keaveney, S. M. (1995), "Customer switching behavior in service industries: an exploratory study" Journal of Marketing, Vol. 59, No. 2, pp.71-82

Lemon, K., Rust, R.T. and Zeithaml, V.A. (2001), "What drives customer equity", Marketing Management, Vol. 10, No. 1, pp.20-25

Marsden, P. Samson, A. and Upton, N (2005), "Advocacy Drives Growth", Brand Strategy, Vol. 198, (Dec-Jan), pp.45-47

Malthouse, E. C.and Blattberg, R. C. (2005), "Can We Predict Customer Lifetime Value?", Journal of Interactive Marketing, Vol. 19, No. 1, pp.2-16

McDonald, M., Rogers, B. and Woodburn, D. (2000), Key Customers: How to Manage them Profitably, Oxford, Butterworth-Heinemann

Murray, K.B. (1991), "A Test of Services Marketing Theory - Consumer Information Acquisition Activities", Journal of Marketing, Vol. 55, No.1, pp.10-25

Patton, E. \& Appelbaum, S.H. (2003), "The case for case studies in management research", Management Research News, Vol. 26, No. 5, pp.60-71

Reichheld, F. F. (1996), The Loyalty Effect, Boston, Harvard Business School Press

Reichheld, F. F. (2003), "The One Number You Need to Grow", Harvard Business Review, Vol. 81, No. 12, pp.46-54

Reichheld, F.F and Sasser Jr, W.E. (1990), "Zero Defections: Quality Comes to Services", Harvard Business Review, Vol. 68, No. 5, pp.105-111

Reichheld, F.F. and Schefter, P. (2000), "E-loyalty: Your Secret Weapon on the Web", Harvard Business Review, Vol. 78, No. 4, pp.105-113. July/Aug

Reinartz, W.J. and Kumar, V. (2002), "The Mismanagement of Customer Loyalty", Harvard Business Review, Vol. 80, No. 7, pp.86-94

Rust, R.T., Lemon, K.N. and Zeithaml, V.A. (2001), "Where should the next marketing dollar go?", Marketing Management, Vol. 10, No. 3, pp.24-28.

Rust, R.T., Lemon, K.N. and Zeithaml, V.A. (2004), "Return on Marketing: Using Customer Equity to Focus Marketing Strategy," Journal of Marketing, Vol. 68 No. 1, pp. 109-127.

Ryals, L.J. (2002), The Total Value of the Customer and Targeted Marketing Strategies, Cranfield School of Management, Cranfield, PhD thesis.

Ryals, L.J. (2003), "Making Customers pay: Measuring and Managing Customer Risk and Returns", Journal of Strategic Marketing, Vol. 11, No. 3, pp.165-176 
Ryals, L.J. (2005), "Making Customer Relationship Management Work: The Measurement and Profitable Management of Customer Relationships", Journal of Marketing, Vol. 69, No. 4, pp.252-261

Ryals, L.J. and Knox, S.D. (2004), "Measuring Risk-adjusted Customer Lifetime Value and its Impact on Relationship Marketing Strategies and Shareholder Value", European Journal of Marketing, Vol. 39, No. 5/6, pp.456-472

Srivastava, R.K., Shervani, T.A. and Fahey, L. (1998), "Market-Based Assets and Shareholder Value: A Framework for Analysis", Journal of Marketing, Vol. 62, No. 1, pp.2-18

Stahl, H.K. Matzler, K. and Hinterhuber, H. H. (2003), "Linking customer lifetime value with shareholder value", Industrial Marketing Management, Vol. 32, No. 4, pp.267-279

Story, V., Hurdley, L., Smith, G. and Saker, J. (2001), "Methodological and Practical Implications of the Delphi Technique in Marketing Decision-Making: A ReAssessment", The Marketing Review, Vol. 1, pp.487-504

Thomas, J.S., Reinartz, W. And Kumar, V. (2004), "Getting the most out of All your Customers”, Harvard Business Review, Vol. 82, No. 7/8, pp.116-123. July/August

Thomke, S. and Von Hippel, E. (2002), "Customers as Innovators: A New Way to Create Value", Harvard Business Review, Vol. 80, No. 4, pp.74-85

Wilson C. (1996), Profitable Customers, London, Kogan Page

Womack, J.P., Jones, D.T. and Roos, D. (1990). The machine that changed the world, New York, Rawson Associates

Yin, R.K. (2002), Case Study Research - Design And Methods, Thousand Oaks, Sage Publications, Chaps. 1-4 pp 1-108.

Zeithaml, V.A., Rust, R.T. and Lemon, K.N. (2001), "The Customer Pyramid: Creating and Serving Profitable Customers", California Management Review, Vol. 43, No. 4, pp.118-142 
Figure 1: Two sources of value from a customer

Financial value

Customer lifetime value/ customer equity

May include adjustments for risk and for potential
Indirect value

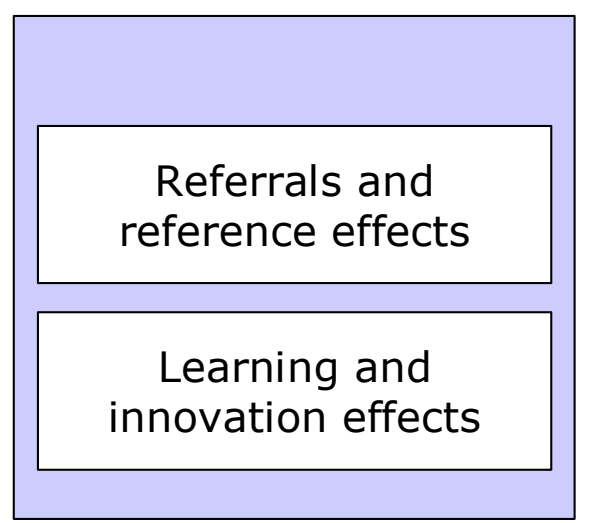


Figure 2: Financial versus Indirect value

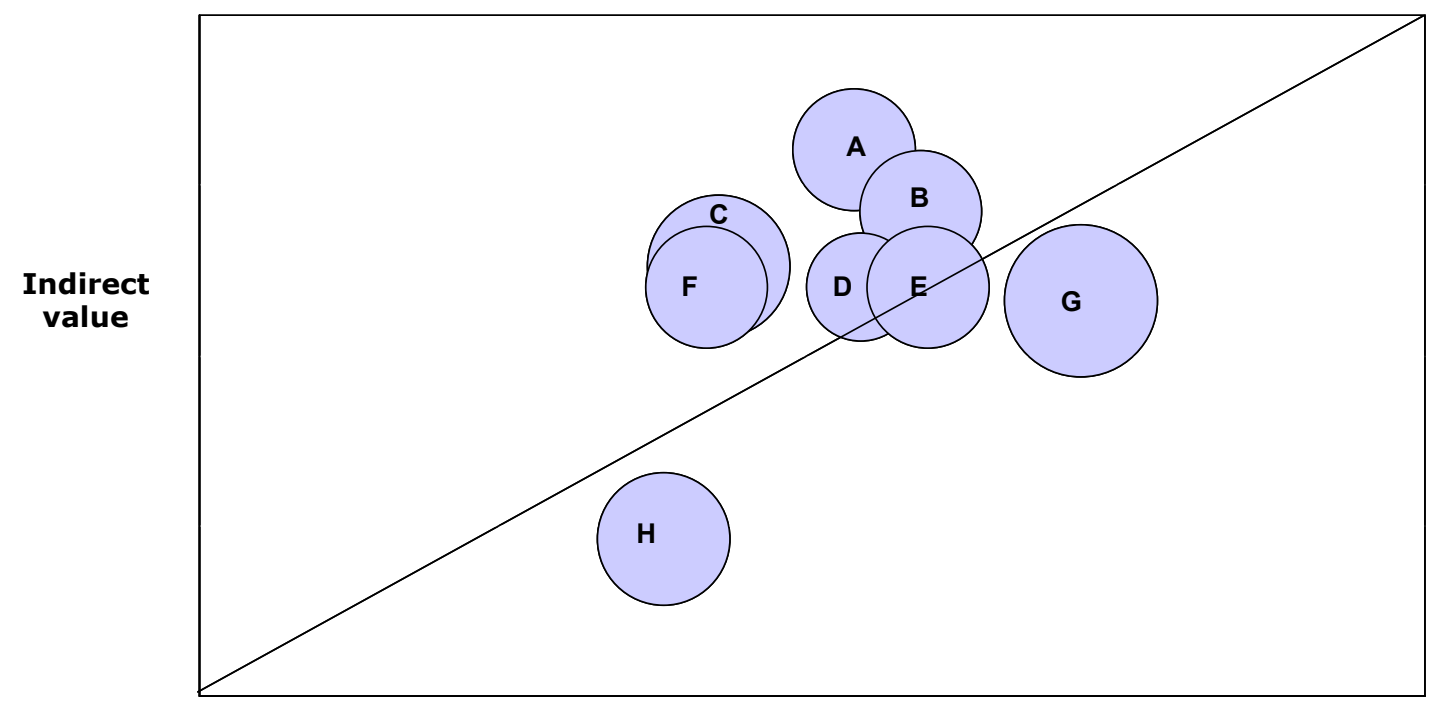

Financial value (customer lifetime value) 
Figure 3: Key customer matrix

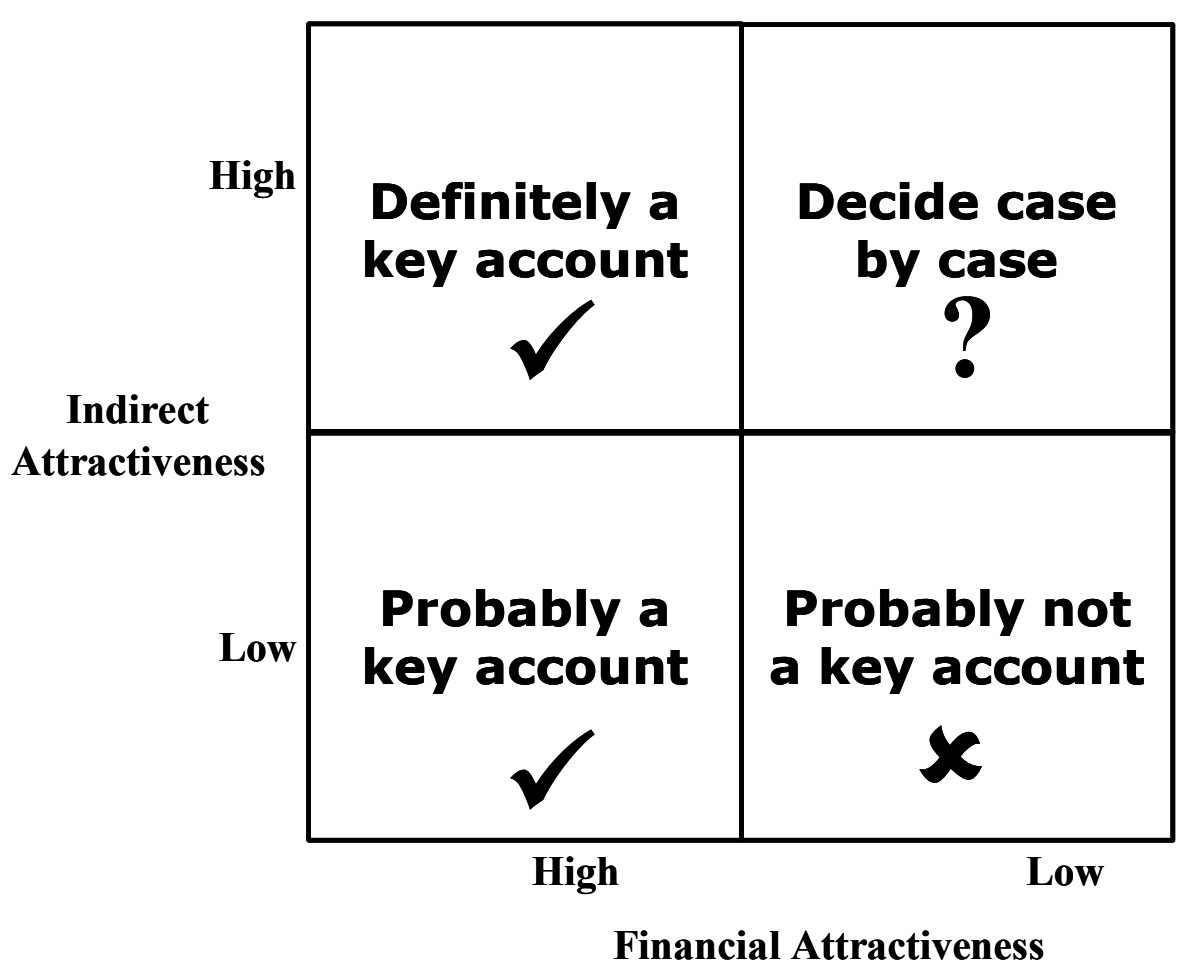


Table 1: Financial approaches to the value of the customer

\begin{tabular}{|c|c|c|c|c|}
\hline Approach & Definition & Advantages & Disadvantages & Application to marketing practice \\
\hline $\begin{array}{l}\text { Customer } \\
\text { lifetime value }\end{array}$ & $\begin{array}{l}\text { Remaining value of customer } \\
\text { relationship (forecast). }\end{array}$ & $\begin{array}{l}\text { Takes future into account. } \\
\text { Returns can vary according } \\
\text { to levels of investment. }\end{array}$ & $\begin{array}{l}\text { Forecasting difficulties and issues } \\
\text { with treatment of discounting and } \\
\text { risk. } \\
\text { Treatment of lost customers } \\
\text { problematic. } \\
\text { Indirect sources of value from } \\
\text { customers not included. }\end{array}$ & $\begin{array}{l}\text { Matching customer management to } \\
\text { payback (supports asset } \\
\text { management approach). } \\
\text { Customer segmentation and } \\
\text { differentiated strategy. }\end{array}$ \\
\hline $\begin{array}{l}\text { Customer } \\
\text { equity }\end{array}$ & $\begin{array}{l}\text { Remaining plus potential value } \\
\text { of customer base ( } \sum \text { customer } \\
\text { lifetime value). }\end{array}$ & $\begin{array}{l}\text { Looks at whole of customer } \\
\text { base (portfolio } \\
\text { management). } \\
\text { Linked to value of firm. }\end{array}$ & $\begin{array}{l}\text { Forecasting difficulties and issues } \\
\text { with treatment of discounting and } \\
\text { risk. } \\
\text { Treatment of lost customers } \\
\text { problematic. } \\
\text { May still need to look at individual } \\
\text { customers in business-to-business } \\
\text { settings. } \\
\text { Indirect sources of value from } \\
\text { customers not included. }\end{array}$ & $\begin{array}{l}\text { Customer portfolio management / } \\
\text { maximising customer assets. } \\
\text { Balancing customer acquisition and } \\
\text { retention budget. } \\
\text { Evaluating communication strategy / } \\
\text { marketing campaigns. }\end{array}$ \\
\hline
\end{tabular}


Table 2: The financial impact of indirect benefits

\begin{tabular}{|c|c|c|}
\hline $\begin{array}{l}\text { Indirect } \\
\text { benefit }\end{array}$ & $\begin{array}{l}\text { Financial impact on value } \\
\text { of customer asset }\end{array}$ & Financial impact on firm \\
\hline $\begin{array}{l}\text { Advocacy } \\
\text { (Referrals) }\end{array}$ & None & $\begin{array}{l}\text { Reduced customer acquisition costs; } \\
\text { higher lifetime value on acquired } \\
\text { customers }\end{array}$ \\
\hline Reference & None & $\begin{array}{l}\text { Reduced customer acquisition costs; } \\
\text { higher lifetime value on acquired } \\
\text { customers }\end{array}$ \\
\hline Learning & May reduce costs & $\begin{array}{l}\text { May reduce overall costs, or increase } \\
\text { revenues if learning opens up new } \\
\text { markets }\end{array}$ \\
\hline Innovation & $\begin{array}{l}\text { May increase revenues } \\
\text { (product innovation) or } \\
\text { reduce costs (process } \\
\text { innovation) }\end{array}$ & $\begin{array}{l}\text { May increase overall revenues if product } \\
\text { innovation is wider than customer- } \\
\text { specific innovation; may reduce overall } \\
\text { costs through process efficiencies }\end{array}$ \\
\hline
\end{tabular}


Table 3: Indirect attractiveness factors identified using unprompted WSS process

\begin{tabular}{ll}
\hline \hline $\begin{array}{l}\text { Relational attractiveness } \\
\text { factors (unprompted) }\end{array}$ & Definition \\
\hline Profile (referenceability) & $\begin{array}{l}\text { Size of customer / Standing in industry / degree to which } \\
\text { relationship enhances supplier's reputation }\end{array}$ \\
Relationship & Access barriers / depth of relationship (no. of contacts) \\
Resources & Time and people required to resource relationship \\
Skill Demands & Level of people required
\end{tabular}


Table 4: Probabilistic valuation of Customer G's indirect value

\begin{tabular}{|c|c|c|c|c|c|}
\hline & Item & Yr 1 & Yr 2 & Yr 3 & $\overline{Y \text { Yr } 4}$ \\
\hline a & $\begin{array}{l}\text { Profit on additional } \\
\text { business }\end{array}$ & 112,220 & 561,100 & $1,009,980$ & $1,458,860$ \\
\hline b & $\%$ Probability without G & $0 \%$ & $0 \%$ & $0 \%$ & $0 \%$ \\
\hline c & $\%$ Probability with G & $100 \%$ & $40 \%$ & $16 \%$ & $6 \%$ \\
\hline$d$ & Increase in probability (c-b) & $100 \%$ & $40 \%$ & $16 \%$ & $6 \%$ \\
\hline e & $\begin{array}{l}\text { Expected Monetary Value } \\
\text { (a } \times \text { d) }\end{array}$ & 112,220 & 224,440 & 161,597 & 87,532 \\
\hline $\begin{array}{l}g \\
h\end{array}$ & $\begin{array}{l}\text { Discount Factor } \\
\text { Net Present Value (e x g) } \\
\text { TOTAL }\end{array}$ & $\begin{array}{r}.909 \\
102,008\end{array}$ & $\begin{array}{r}.826 \\
185,387\end{array}$ & $\begin{array}{r}.751 \\
121,359\end{array}$ & $\begin{array}{r}.683 \\
59,784 \\
£ 468.538\end{array}$ \\
\hline
\end{tabular}


Table 5: Satisfaction, advocacy and complaints

\begin{tabular}{|c|c|c|c|c|}
\hline & Satisfaction* & $\begin{array}{l}\text { Very likely to } \\
\text { refer }\end{array}$ & $\begin{array}{l}\text { Quite likely to } \\
\text { refer }\end{array}$ & Complaints $^{\star *}$ \\
\hline Loans dept \% & 55 & 39 & 39 & 16 \\
\hline $\begin{array}{l}\text { Company overall } \\
\%\end{array}$ & 53 & 33 & 42 & $<10$ \\
\hline
\end{tabular}


Table 6: Advocacy sources and risk profile

\begin{tabular}{|c|c|c|}
\hline $\begin{array}{l}\text { Relationship } \\
\text { to advocate }\end{array}$ & $\begin{array}{l}\text { Source } \\
\text { referral }\end{array}$ & Risk profile and application behaviour \\
\hline Family & $\begin{array}{l}\text { Usually, parents } \\
\text { referring } \\
\text { children }^{*}\end{array}$ & $\begin{array}{l}\text { Same. Children's risk profile felt to be same as that of } \\
\text { parents. Thought to be the most frequent type of } \\
\text { referral. }\end{array}$ \\
\hline Peer & $\begin{array}{l}\text { Friends (tended } \\
\text { to be younger } \\
\text { customers) }\end{array}$ & $\begin{array}{l}\text { Similar. Friends may even accompany one another into } \\
\text { the branch to apply for loans at the same time. }\end{array}$ \\
\hline Colleague & Workmates & $\begin{array}{l}\text { Similar. Can result in multiple customers - several } \\
\text { customers from same workplace may follow shortly } \\
\text { after one customer recommends. Loans may be for } \\
\text { same purpose (e.g. car buying), and purpose of loan is } \\
\text { known to influence risk. }\end{array}$ \\
\hline
\end{tabular}

* 'Children' here merely indicates the relationship to the referrer, as all the customers under discussion are adults. 
Table 7: Three methods for valuing indirect benefits

\begin{tabular}{|c|c|c|c|c|}
\hline & Method & Process & Advantages & Disadvantages \\
\hline \multicolumn{5}{|c|}{ Case study 1: } \\
\hline & WSS & $\begin{array}{l}\text { Identify attractiveness } \\
\text { factors, apply } \\
\text { importance } \\
\text { weighting, score each } \\
\text { customer. }\end{array}$ & $\begin{array}{l}\text { Conceptually } \\
\text { straightforward, may } \\
\text { help identify key } \\
\text { accounts. }\end{array}$ & $\begin{array}{l}\text { Managers may } \\
\text { tend to conflate } \\
\text { financial size or } \\
\text { profitability of } \\
\text { customer with high } \\
\text { indirect value. }\end{array}$ \\
\hline 2 & Probabilistic & $\begin{array}{l}\text { Change in probability } \\
\text { of benefit multiplied } \\
\text { by financial value of } \\
\text { benefit. }\end{array}$ & $\begin{array}{l}\text { Reduces double } \\
\text { counting issue and } \\
\text { problem of 'would have } \\
\text { happened anyway'; } \\
\text { results in substantial } \\
\text { differences to value of } \\
\text { customer. }\end{array}$ & $\begin{array}{l}\text { Requires a series } \\
\text { of assumptions } \\
\text { about timing and } \\
\text { financial amount of } \\
\text { relational benefits. }\end{array}$ \\
\hline \multicolumn{5}{|c|}{ Case study 2: } \\
\hline 3 & $\begin{array}{l}\text { Triangulated, } \\
\text { based on } \\
\text { advocacy rates } \\
\text { and incoming } \\
\text { customer } \\
\text { comments }\end{array}$ & $\begin{array}{l}\text { Collect data on intent } \\
\text { to refer, compare this } \\
\text { with predicted actual } \\
\text { referral and } \\
\text { conversion rates, } \\
\text { check against } \\
\text { incoming customers } \\
\text { where they indicate } \\
\text { they came through } \\
\text { referrals }\end{array}$ & $\begin{array}{l}\text { Minimises need for } \\
\text { forecasting even where } \\
\text { actual referrals are not } \\
\text { recorded. May } \\
\text { encourage recording of } \\
\text { referrals. Produced } \\
\text { indication that referred } \\
\text { customers may have } \\
\text { similar risk profile to } \\
\text { their advocates. }\end{array}$ & $\begin{array}{l}\text { Collecting } \\
\text { advocacy data from } \\
\text { incoming } \\
\text { customers may be } \\
\text { cumbersome. }\end{array}$ \\
\hline
\end{tabular}


Table 8: Summary of findings and future research directions

\begin{tabular}{|c|c|c|}
\hline & $\begin{array}{l}\text { Case study } 1 \\
\text { Business-to-business }\end{array}$ & $\begin{array}{l}\text { Case study } 2 \\
\text { Business-to-consumer }\end{array}$ \\
\hline $\begin{array}{l}\text { Financial } \\
\text { valuation } \\
\text { process }\end{array}$ & Customer lifetime value & Customer equity \\
\hline $\begin{array}{l}\text { Relational } \\
\text { valuation } \\
\text { process }\end{array}$ & $\begin{array}{l}\text { 1. WSS: intuitive and easy to } \\
\text { use but may tend to } \\
\text { conflate financial and } \\
\text { indirect value. } \\
\text { 2. Probabilistic approach: } \\
\text { increase in probability of } \\
\text { obtaining benefit multiplied } \\
\text { by value of benefit. }\end{array}$ & $\begin{array}{l}\text { 3. Estimated value of advocacy } \\
\text { based on previous research } \\
\text { and behaviour, triangulated } \\
\text { with branch manager } \\
\text { perception. }\end{array}$ \\
\hline $\begin{array}{l}\text { Impact on } \\
\text { perceived } \\
\text { value of } \\
\text { customer }\end{array}$ & $\begin{array}{l}\text { Considerable for some customers, } \\
\text { less for others. }\end{array}$ & $\begin{array}{l}\text { Small but potentially profitable } \\
\text { incremental business, especially if } \\
\text { risk taken into account. }\end{array}$ \\
\hline $\begin{array}{l}\text { Additional } \\
\text { issues raised }\end{array}$ & $\begin{array}{l}\text { a. Are financial and indirect } \\
\text { value positively related? } \\
\text { b. How can predictive } \\
\text { accuracy in probabilistic } \\
\text { method be gauged? }\end{array}$ & $\begin{array}{l}\text { c. Is the risk / return profile of } \\
\text { referred customers similar to } \\
\text { that of the referrer? } \\
\text { d. Is indirect value in business- } \\
\text { to-consumer confined to } \\
\text { advocacy? }\end{array}$ \\
\hline
\end{tabular}

